\title{
STUDY OF POPULATION DYNAMICS AND EXPLOITATION RATES OF CRAYFISH (PANULIRUS SPP) IN SPERMONDE WATERS, MAKASSAR STRAIT
}

\author{
Budiman Yunus ${ }^{1 凹 i D}$, Basse Siang Parawansa ${ }^{1}$ \\ 1 Department of Fisheries, Faculty of Marine Science and Fisheries, Hasanuddin University, \\ Indonesia
}

DOI: https://doi.org/10.29121/granthaalayah.v9.i3.2021.3697

Article Type: Research Article

Article Citation: Budiman Yunus, and Basse Siang Parawansa. (2021). STUDY OF POPULATION DYNAMICS AND EXPLOITATION RATES OF CRAYFISH (PANULIRUS SPP) IN SPERMONDE WATERS, MAKASSAR STRAIT. International Journal of Research -GRANTHAALAYAH, 9(3), 10-17.

https://doi.org/10.29121/granthaa layah.v9.i3.2021.3697

Received Date: 13 February 2021

Accepted Date: 18 March 2021

Keywords:

Ecology

Population Dynamics

Lobster

Spermonde Waters

\section{ABSTRACT}

To stimulate catch production and wise management patterns, research is carried out on the study of ecological aspects, estimates of population dynamics and exploitation rates of crayfish (Panulirus Spp) in the Spermonde waters of the Makassar Strait. Based on the COA (Correspondence Analysis) (Ludwig and Reynold, 1988), as well as the analysis of Von Bertalanffy (1938, in Sparre et al., 1989), it was found that the micro-habitat of Panulirus spp., Generally co-exist with massive coral species Alcyonaria (Sarcophyton, Heliophora, and Tubipora), and branching reefs of the Acropora species (Goniopora and Pavona), as well as living with algal grass species of Caulerpa and Halimeda. The growth pattern of Panulirus lobster follows the equation Lt $=46.3561$ (1- e - 0.1738 $(t+1.7827))$, which means that the length decreases at relatively old age. The total mortality coefficient (Z) of population is $0.5066 /$ year, this is relatively the same as the ideal mortality (M) which means optimal utilization, but it is necessary to select catch sizes that are larger than 24 $27 \mathrm{~cm}$ (in the range of $34-46 \mathrm{~cm}$ ).

\section{INTRODUCTION}

Until now, the utilization of crayfish as a high economic resource has not been optimal, especially since the issuance of Presidential Decree No.39 / 80 concerning the prohibition of trawling, despite the increasing demands of domestic and foreign food needs. The need for lobster exports to importing countries such as China, Hong Kong, Taiwan, Japan, Malaysia, Singapore, Australia and the United States is increasing. The largest data on lobster (ton) export shipments that have been carried out by Indonesia to these 8 countries for the last 5 years, are as follows: $2.066 .38 ; 301.77 ; 404.25 ; 21.74 ; 119.93 ; 109.32 ; 48.45$; and 1.97 respectively.

Since then until now the number of exports has decreased even though the demand for these countries is increasing (Rahmah, 2019). The decrease in catch production is indicated by 2 assumptions; first, because fishing technology that is capable of producing high production has not been attempted, secondly, the potential for resources has decreased due to unwise management so far. To avoid the possibility of over-exploitation (over 
fishing) and / or over-investment in lobster biota, it is necessary to study the ecological aspects, population dynamics and exploitation level of these crayfish in formulating management policies.

\section{METHOD OF RESEARCH}

This research was conducted for approximately 3 months, from the beginning of April to the end of June 2019 in the waters around the Spermonde Islands, Makassar Strait.

As the research target animal is crayfish (Panulirus spp) obtained from the catch of fishermen operating around Spermonde waters using bottom nets, bottom traps, and by diving. Examples of caught lobsters were preserved with formaldehyde [10] in a jar (25cm diameter, $40 \mathrm{~cm}$ high). Shrimp length is measured with a $0.1 \mathrm{~cm}$ ruler (Fig. 1).

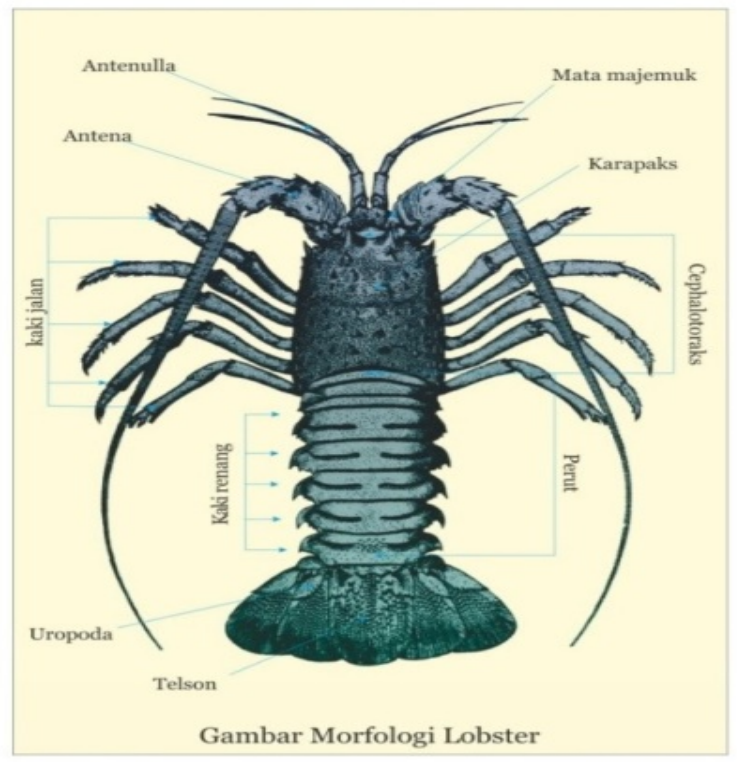

Figure 1: An example of a fresh display of lobster Panulirus sp.

(https://kkp.go.id/djprl/bpsplmakassar/page/3754-lobster

\subsection{DATA COLLECTION TECHNIQUE}

Research stations are determined based on which islands are considered high potential for crayfish in the waters of the Spermonde Islands (Fig. 2).



Figure 2: Map of the Spermonde Islands, Makassar Strait 


\subsection{ANALYSIS PROCEDURE}

Microhabitat: Obtaining data is divided into two parts, namely primary data and secondary data. Primary data is obtained directly in the field or through fishermen, while secondary data is obtained from the information section of the Paotere Landing and Auction Technical Implementation Unit, Makassar Marine Fisheries Service. Because the number of lobster catches from fishermen is small, the sample is recorded as a whole. The total length of lobsters was directly measured at the location by measuring the long distance between the leading end of the antenna and the telsom end.

To determine the microhabitat of lobsters, a comparative analysis was carried out based on the suitability of the habitat to physical and biological factors through the COA approach (Correspondence Analysis) according to Ludwig and Reynolds (1988).

Growth: The growth model used in data analysis is the Von Bertalanffy model (1938 in Sparre et al., 1989), namely: $\mathrm{Lt}=\mathrm{L}_{\mathrm{oo}}\left(1-\mathrm{e}-\mathrm{K}(\mathrm{t}-\mathrm{to})\right.$ ) (Information; $\mathrm{Lt}=$ length at time $\mathrm{t}, \mathrm{L}_{\mathrm{oo}}=$ maximum length, $\mathrm{K}=$ growth rate coefficient, and $t_{0}=$ theoretical age). To obtain the $\mathrm{L}_{0 o}$ and $\mathrm{K}$ values, first transform the relative growth (dL/dt) with the mean length, so that $\mathrm{dL} / \mathrm{dt}=\mathrm{K} \mathrm{L}_{\mathrm{oo}}-\mathrm{KL}=(\mathrm{Lt}+\mathrm{Lt}+1) / 2$. This equation is linear regression, where $\mathrm{a}=\mathrm{K} \mathrm{L}_{\mathrm{oo}}, \mathrm{b}=-\mathrm{K}, \mathrm{while} \mathrm{X}$ $=t_{0}$, is obtained from the Von Bertalanffy equation which is derived into the equation $-\ln \left[\left(\mathrm{L}_{o o}-\mathrm{Lt}\right) / \mathrm{L}_{o o}\right]=-\mathrm{Kt}_{0}+\mathrm{Kt}$ where $a=-K t_{0}, b=K$. If $Y=0$ and $X=t_{0}$, then $t_{0}=a /-b$, whereas to obtain the relative age of various lobster lengths, then from the derivative, if $Y=0$ and $X=t_{0}$, then $t_{0}=a /-b$, whereas $t_{0}$ get the relative age of various lobster lengths, then the derivative of Von Bertalanffy obtained the equation $t=1 / \mathrm{K} . \ln \left[\left(\mathrm{L}_{\mathrm{oo}}\right) /\left(\mathrm{L}_{\mathrm{oo}}-\mathrm{Lt}\right)\right]+\left(\mathrm{t}_{\mathrm{o}}\right)$.

Age group: Analysis to estimate age groups of lobsters, namely using the long frequency method (Batacharya, 1967), where the sum of each length is converted into a logarithmic equation (log f). By mapping the mean value of each length class as the $\mathrm{X}$ axis to the logarithm difference of the frequency class length as the $\mathrm{Y}$ axis, a straight line can be drawn from the scattered point to the lowest point. The intersection of the lines on the X-axis represents groups of age and mode of length, respectively.

Mortality: To estimate the instantaneous mortality rate (Z), the analysis of Beverton and Holt (1956, in Sparre et al, 1989) is used, namely $Z=K\left(L_{o o}-\mathrm{L}\right) /\left(L^{\prime}\right)$, where $Z$ = instantaneous mortality rate, $K=$ growth coefficient annual, $\mathrm{L}=$ average length $(\mathrm{cm})$ caught and $\mathrm{L}^{\prime}=$ minimum limit $(\mathrm{cm})$ of length class caught. Pauly's (1980) empirical approach was used to compare the mortality value obtained by this analysis, namely through the logarithmic equation, as follows: $\log M=-0.006-0.279 \log L_{o o}+0.6543 \log K+0.4634 \log T$, where $M=$ natural mortality and $T$ = mean temperature of the waters. Meanwhile, the mortality due to capture (F) was obtained through $\mathrm{F} / \mathrm{Z}+\mathrm{M} / \mathrm{Z}=$ 1.0 .

Level of exploitation: In estimating the potential of the available crayfish population, data on the catch and the number of fishing gear units for the last several time (months or years) were used which were obtained based on information from fishermen and from related fisheries agencies. The data were analyzed by the method of Leslie and DeLury (Everhart, Eipper and Young, 1975 in Effendie, 1979), as follows; C/F = q No e-qGt, where C/F = catch per unit effort, $\mathrm{q}$ = catch coefficient (cath ability), $\mathrm{No}=$ initial population, and Gt = cumulative fishing effort. To determine the values of $a$ and $b$ in the regression, the equation must first be logarized naturally so that it becomes: $\ln C / F=\ln$ q No - q Gt. From these values, the initial population can be determined by means of a formula; $a=\ln q$ No, where No $=\mathrm{e} a / \mathrm{q}, \mathrm{q}=-\mathrm{b}, \mathrm{a}=$ constant, $\mathrm{q}=$ catch (cathability). In determining the estimation of MSY (Maximum Sustainable Yield) and optimal catch, the Schaefer (1954, in Sparre et al., 1989) production method was used; C/F = a - bF. From the regression, the $a$ and $b$ values were obtained which could predict the optimum MSY and $F$ estimates through the formula; $M S Y=a^{2} / 4 b$, and $F_{\text {opt. }}=a / 2 b$. to get a range of exploitation levels, another analysis was also carried out, namely the Fox model approach (1970), namely; $C / F=a e^{-b F}$. By substituting the $a$ and $b$ values from the equation, MSY can be predicted as sustainable catch production.

\section{RESULTS AND DISCUSSION}

\subsection{MICROHABITAT}

In general, the ecological data for 3 lobster species are based on sample units with ecological factors around the Makassar Strait Spermonde waters (Table 1). 
Table 1: Ecological data 3 lobster species based on community sample units with water quality in the Makassar Strait Spermonde waters

\begin{tabular}{|c|c|c|c|c|c|c|}
\hline \multirow{2}{*}{ No. } & Species & \multicolumn{4}{|c|}{ Sample unit (No. Coral Community) } \\
\cline { 2 - 7 } & & $(1)$ & $(2)$ & $(3)$ & $(4)$ & $(5)$ \\
\hline & Main Species of Lobster & & & & & \\
1. & Panulirus homarus & 10 & 20 & 10 & 15 & 20 \\
2. & P. longipes & 9 & 5 & 14 & 13 & 12 \\
3. & 5 & 7 & 9 & 6 & 7 \\
& P. versicolor & & & & & \\
4. & Other species in the same habitat & & 5 & 7 & 2 & 5 \\
5. & Goniopora & 8 & 7 & 11 & 3 & 7 \\
6. & Pavona & 2 & 2 & 4 & 1 & 5 \\
7. & Heliopora & 5 & 7 & 7 & 1 & 4 \\
8. & Sarcophiton & 6 & 5 & 5 & 3 & 7 \\
9. & Tubipora & 5 & 3 & 3 & 1 & 3 \\
10. & Caulerpa & 4 & 3 & 0 & 5 \\
\hline No. & Ecological factors (Water Quality) & $(1)$ & $(2)$ & $(3)$ & $(4)$ & $(5)$ \\
\hline 1. & Temperature ( $\left.{ }^{\circ} \mathrm{C}\right)$ & 27 & 24 & 28 & 28,5 & 29 \\
2. & Salinity (o/oo) & 34 & 36 & 36 & 35 & 34 \\
3. & Acidity (pH) & 8 & 7,8 & 7,8 & 9 & 9,3 \\
4. & Light intensity (\%) & 98 & 90 & 95 & 90 & 110 \\
\hline
\end{tabular}

The suitability of biota with ecological factors in coral reef communities shows the closeness of ecological relationships in spatial units based on COA analysis (Orloci, et al. 1985). This shows the suitability of the habitat with 4 ecological factors in relatively the same ordinate space. Ecological analysis shows that in a large area there is an ecological space (niche) as a lobster microhabitat which is indicated by the coexistence of coral reef species and algal grass with its water quality (Table 1).

Microhabitat of the 3 main species of crayfish are found both in groups and in solitary with massive reefs of the Alcyonari species (Sarcophyton, Heliophora, and Tubipora) and branching reefs of the Acropora species (Goniopora and Pavona) and live with algae grasses of the Caulerpa and Halimeda species. While the supporting ecological factors in the association of the microhabitat are temperature $24-29{ }^{\circ} \mathrm{C}$, salinity $34-36 \%$ oo, muddy sand gravel substrate with a composition of 3: 2: 1, pH 7,8-9,3, and brightness 0,90- 1.20 (Table 2 and Table 3)

Table 2: Relation of COA (Spi) - [V] components as species association to coral reef communities

\begin{tabular}{|c|c|c|c|}
\hline \multirow{2}{*}{ Spesies $\left(\mathrm{Sp}_{\mathrm{i}}\right)$} & \multicolumn{3}{|c|}{ COA Component } \\
\cline { 2 - 4 } & $\mathrm{I}$ & $\mathrm{II}$ & III \\
\hline [V]: 1. & 1.0 & $-1,675$ & $-0,745$ \\
2. & 1.0 & 2,706 & $-1,300$ \\
3. & 1.0 & 1,987 & $-1,342$ \\
4. & 1.0 & $-1,557$ & $-0,983$ \\
5. & 1.0 & 0,013 & $-0,115$ \\
6. & 1.0 & 0,324 & $-1,732$ \\
7. & 1.0 & $-0,317$ & $-0,964$ \\
8. & 1.0 & 0,997 & $-0,137$ \\
9. & 1.0 & $-1,075$ & $-0,065$ \\
10. & 1.0 & 0,135 & $-0,012$ \\
\hline
\end{tabular}

Table 3: Relationship between $\mathrm{COA}\left(\mathrm{SU}_{\mathrm{i}}\right)-[\mathrm{Y}]$ components as species association with ecological factors

\begin{tabular}{|c|c|c|c|}
\hline Sample Unit & \multicolumn{3}{|c|}{ COA Component } \\
\cline { 2 - 4 }$\left(\mathrm{SU}_{\mathrm{i}}\right)$ & $\mathrm{I}$ & $\mathrm{II}$ & $\mathrm{III}$ \\
\hline$[\mathrm{Y}]: 1$. & 1.0 & $-0,305$ & $-0,364$ \\
2. & 1.0 & 0,871 & $-0,039$ \\
\hline
\end{tabular}




\begin{tabular}{|c|c|c|c|}
\hline 3. & 1.0 & 0,730 & $-0,118$ \\
4. & 1.0 & $-1,974$ & $-1,098$ \\
5. & 1.0 & 1,077 & $-1,132$ \\
\hline
\end{tabular}

\subsection{COMPOSITION OF SPECIES AND SIZE}

The population of crayfish around the Spermonde Islands consists of 3 dominant species, namely; Panulirus homarus, $P$. longipes, and $P$. versicolor. Of this population, $P$. homarus was mostly caught by fishermen on the islands of Kodingareng, Balanglompo, Baranglompo, Barangcaddi and Samalona. Then followed P. longipes and P. versicolor. Of the 335 P. homarus crayfish, the highest frequency was found with a carapace length range of $22.0-25.9 \mathrm{~cm}$, amounting to 37 individuals (12.87\%).

The length distribution of lobster carapace (Figure 3) explains that in Spermonde waters during the observation period there were 4 long distribution peaks, respectively as follows; $17.33 \mathrm{~cm}$ (32 ind.), $20.73 \mathrm{~cm}$ (43 ind.), $25.65 \mathrm{~cm}$ (49 ind.) and $28.35 \mathrm{~cm}$ (47 ind.)



Figure 3: Histogram of the carapace length distribution of Panulirus sp. in the waters of Spermonde, Makassar Strait.

\subsection{AGE GROUP}

Bhattacharya's analysis shows that there are 4 age groups of Panulirus $s p$ in the Spermonde waters. With the same method, 4 length modes were also obtained from each carapace length class. From this analysis, it is predicted that the crayfish found in Spermonde waters will consist of 4 subpopulations or 4 age groups, namely subpopulations I to IV with a range of carapace lengths sequentially as in Table 4.

Table 4: Length range of Panulirus sp carapace, relative age and long mode in the Makassar Strait Spermonde waters.

\begin{tabular}{|c|c|c|}
\hline Carapace length range $(\mathrm{cm})$ & Relative age group & Carapace mode \\
\hline $15,85-19,86$ & I & 17,33 \\
$19,86-22,45$ & II & 20,73 \\
$22,45-26,72$ & III & 25,65 \\
$27,90-32,0$ & IV & 28,35 \\
\hline
\end{tabular}

\subsection{GROWTH}

Based on the Gulland and Holt Plot methods, the growth of Panulirus sp., can reach a maximum length of $\mathrm{L}_{\mathrm{oo}}=$ $46.3561 \mathrm{~cm}$ with a growth coefficient rate of $\mathrm{K}=0.1738$ per year. Von Bertalanffy's analysis showed the age acquisition of crayfish varieties at the first length $\left(t_{0}\right)=-1.7827 \mathrm{~cm}$. The growth of Panulirus crayfish, especially 
Panulirus homarus which is dominant in the waters of the Spermonde Islands follows the equation model Lt $=$ 46.3561 [ $1-\mathrm{e}-0.1738(\mathrm{t}+1.7827)]$. This growth shows that the increase in size is decreasing at the relatively old age compared to the relatively young age. The relative age distribution of crayfish in several length ranges, shown by the derivative of the formula Von Bertalanffy $t=[(1 / 0.1738)(\ln 46.3561) /(46.3561-\mathrm{Lt})]-1.7827$.

The small Panulirus spp $(15.8 \mathrm{~cm})$ in this observation was thought to be 0.62 years old, while the largest (32 $\mathrm{cm}$ ) was thought to be 5 years old. And the long range group that was mostly caught (37 ind.) Measuring between $26-27 \mathrm{~cm}$ was thought to be between $2.95-3.21$ years old. Based on the growth rate $(\mathrm{K}=0.1738)$ per year with a carapace length of $32 \mathrm{~cm}$, and to reach the maximum length $\left(\mathrm{L}_{o o}=47 \mathrm{~cm}\right)$, the crayfish in Spermonde waters takes a long time to reach their maximum length.

\subsection{MORTALITY RATE}

There are 2 known mortality rates or mortality rates in fisheries resource management, namely natural mortality (M) and fishing mortality (F). Natural mortality generally depends on environmental factors, while mortality due to fishing is influenced by human exploitation efforts and activities of natural resources.

Through the Beverton and Holt analysis, a total mortality coefficient (Z) of 0.5066 per year was obtained for the crayfish population. This total mortality is relatively the same as the theoretical ideal mortality of 0.5 which indicates optimal utilization is achieved, however, it still needs to develop fishing gear to reach a length greater than the carapace size range of $24-27 \mathrm{~cm}$, which is between $34-46 \mathrm{~cm}$.

\subsection{POTENTIAL AND LEVEL OF EXPLOITATION}

Based on statistical data on catch production and fishing gear units UPT-Paotere Landing and Auction Development, Makassar Marine and Fisheries Service 2013-2018 (Table 5), it is obtained that the production of catch per unit effort (CPUE) is in the range of $58.4360-157.5700 \mathrm{~kg}$ (0.058-0.158 tons). This production is the result of the Schaefer and Gulland Fox model formulations, which are C/F $=4.6012-0.0084 \mathrm{~F}$ and $\mathrm{C} / \mathrm{F}=1.5448 \mathrm{e}^{-0.0022 \mathrm{~F}}$, respectively, and this indicates an unbalanced CPUE production every year, where the CPUE is balanced in the range of $0.59-2.25 \mathrm{~kg} /$ unit effort has been almost doubled.

e

Table 5: Exploitation rates, catch production and CPUE based on the Schaefer and Gulland Fox models

\begin{tabular}{|c|c|c|c|c|c|c|c|c|}
\hline Year & $\begin{array}{l}\text { Production } \\
\text { (Kg) }\end{array}$ & $\begin{array}{l}\text { Fishing gear } \\
\text { (Unit) }\end{array}$ & $\begin{array}{c}\mathrm{C} / \mathrm{F} \\
\mathrm{Kg} / \mathrm{U} / \text { Year }\end{array}$ & $\begin{array}{c}\mathrm{LnC} / \mathrm{F} \\
\mathrm{Kg} / \mathrm{U} / \text { Year }\end{array}$ & \multicolumn{2}{|c|}{ Catch balanced (Kg) } & \multicolumn{2}{|c|}{$\begin{array}{l}\text { CPUE balanced } \\
\text { (Kg/U/Year) }\end{array}$} \\
\hline & & & & & Schaefer & Fox & Schaefer & Fox \\
\hline 2013 & 367,76 & 97 & 3,7913 & 1,3327 & 146,6640 & 66,7263 & 1,5120 & 0,6879 \\
\hline 2014 & 398,29 & 113 & 3,5247 & 1,2597 & 1418828 & 72,6816 & 1,2556 & 0,4332 \\
\hline 2015 & 437,47 & 119 & 3,6762 & 1,3019 & 110,2535 & 70,2219 & 0,9265 & 0,5901 \\
\hline 2016 & 323,93 & 79 & 4,1004 & 1,4111 & 148,5358 & 59,8425 & 1,8802 & 0,7575 \\
\hline 2017 & 290,87 & 73 & 3,9845 & 1,3824 & 157,5267 & 59,4658 & 2,1579 & 0,8146 \\
\hline 2018 & 279,78 & 70 & 3,8927 & 1,3591 & 157,5700 & 58,4360 & 2,2510 & 0,8348 \\
\hline
\end{tabular}

Based on the value of catch production and balanced CPUE, crayfish in Spermonde waters may have overfished, especially for small sizes in specific communities, so that the shrimp has not grown to meet the optimum capacity of the fishing unit (fopt = 273-454 unit) with the production of MSY 630-784 kg (0.63-0.78 tons) per year.

\section{CONCLUSION AND SUGGESTION}

\subsection{CONCLUSION}

Based on the results of research that has been carried out in the Spermonde Islands, Makassar Strait, it can be concluded as follows:

1) Micro-habitat for crayfish (Panulirus spp) is found in groups or solitary with massive reefs from the Alcyonari family (Sarcophyton, Heliophora, and Tubipora) and branching reefs from the Acropora family (Goniopora and Pavona), and live with algal grass from the Caulerpa family and Halimeda. 
2) The population of crayfish in Spermonde waters consists of 3 species, namely; Panulirus homarus, $P$. longipes, and $P$. versicolor. Of this population, $P$. homarus is dominant and mostly caught by fishermen in the Spermonde Islands.

3) There are 4 subpopulations or age groups with a range of carapace lengths, respectively; subpopulations I $(15.8-19.8 \mathrm{~cm})$, II $(19.9-23.9 \mathrm{~cm})$, III $(24.0-27.9 \mathrm{~cm})$, and IV $(28.0-32 \mathrm{~cm})$.

4) The growth of crayfish Panulirus sp., Follows the formula Lt $=46.356\left(1-\mathrm{e}^{-0.1738(t+1.7827)}\right)$ which shows a decreasing increase in size at relatively old ages compared to relatively young ages.

5) The total mortality coefficient ( $\mathrm{Z}$ ) of the crayfish population is 0.5066 / year, this is relatively the same as the ideal mortality of 0.5 which indicates optimal utilization is achieved. But still pay attention to the selectivity of the target catch size under the carapace size range of 34-46 cm.

6) The annual sustainable potential of MSY against Panulirus spp based on the Schaefer and Gulland Fox models in Spermonde waters is $630.0893 \mathrm{~kg}$ ( $0.6301 \mathrm{ton})$ and $783.7561 \mathrm{~kg}(0.7837 \mathrm{ton})$ respectively with optimum effort of 273.8809 and 454,5454 fishing units.

\subsection{SUGGESTION}

It is hoped that in the next study by taking primary data directly to stations that are slightly out of the sub-litoral (continental ridge) by adding parameters of sex-ratio, condition factors, aspects of reproduction, and its relation to ecological parameters.

\section{SOURCES OF FUNDING}

This research received no specific grant from any funding agency in the public, commercial, or not-for-profit sectors.

\section{CONFLICT OF INTEREST}

The author have declared that no competing interests exist.

\section{ACKNOWLEDGMENT}

Thanks to Drs. Abbas, M.Sc., as the Head of the Port Office / Landing Pier and Paotere Fish Auction, as the Technical Implementation Unit of the Ministry of Marine Affairs and Fisheries for moral assistance, material and scientific information contributed during this research.

\section{REFERENCES}

[1] Aziz, K.A. 2013. Estimation of Tropical Fish Population Stocks. Ministry of Education and Culture. Director general of DIKTI-PAU, IPB-Bogor. 115p.

[2] Beverton, R.J.H., and S.J. Holt. 1957. On Dynamics of Exploited Fish Population. Chapman and Hall Pub., London.

[3] Bhattacharya, C.G. 1967. A simple Method of Resolution a Distribution on Into Gasslang Componen Biometrics.

[4] George, R.W. 1968. Tropical Spiny Lobster. Panulirus spp., of Western Australia (and the Indo-West Pasific). J. Roy. Soc. W. Australia.

[5] Gulland, J.A. 1976. Manual of Methods For Fish Stock Assessment. Part I, Fish Population Analysis. Fourth edition, FR/S/M4. FA0, Rome.

[6] Ludwig, J.A and J.F. Reynold, 1988. Statistical Ecology. A Primer on Method and Computing. A WileyInterscience Publication. John Wiley and Sons. New York.

[7] Meadows, P.S., J.I. Campbell. 1988. An Introduction to Marine Science. Department of zoology University of Glasgow. Halsted Press, a Div. of John Wiley and Sons. New York. 2nd ed., 285p (184-216). 
[8] Moosa, M.K. and Aswandy. 1984. Crayfish (Panulirus spp) from Indonesian waters. Indonesian Natural Resources Potential Study Project, LON-LIPI, Jakarta. 47p.

[9] Orloci, L. and N.C. Kenkel. 1985. Introduction to Data Analysis with Examples from Population and Community Ecology. Statistical Ecology Monographs, Vol. 1, International Co-operative Publishing House, Fairland, MD.

[10] Rahmah, L.N.A. 2016. Analisis aliran perdagangan dan strategi pengembangan ekspor lobster indonesia. Masters thesis, Institut Pertanian Bogor.

[11] Sparre, P., E. Ursin and S.C. Venema. 1989. Introduction to Tropical Fish Stock Assessment. Part I-Manual. FAO Fisheries Technical Paper. 306/1 